\title{
CHANGES TO STAFF TRAINING STRATEGIES IN A BUSINESS ORGANISATION IN TERMS OF LEARNING AND COMPETENCE DEVELOPMENT
}

\author{
Birutė Anužienè \\ Klaipèda University, Lithuania \\ Ilona Zubrickienè \\ Klaipèda University, Lithuania \\ Gitana Tolutienè \\ Klaipėda University, Lithuania
}

\begin{abstract}
This paper presents the findings of a study on attitudes of employees of business organisations towards changes in their development strategies in terms of learning and competence development. The study is based on the assumption that the lack of corporate staffs' competences hinders innovation, impairs the quality of activities, while the engrained conventional approach towards staff training prevents from using workplace opportunities of self-study and competence development. The study identifies the following practical issue: conventional staff training, principles and methods of competence development that depend on direct and virtual learning are not always effective lately.

An analysis of the research participants' attitudes can help to answer the following problematic questions in more detail: are the acquisition of competences, trainings held, and employee learning considered identical phenomena? What is the efficiency of staff training and competence development activities or the learning tools applied? What does the application of the principles of staff training and competence development in an organisation mean in practice? The article, therefore, is aimed to analyse the changes in staff development strategies in terms of employee learning and competence development from the perspective of corporate staff.
\end{abstract}

Keywords: competence development, corporate staff development strategies, staff training, learning.

\section{Introduction}

Today's world is changing so fast and employees, accordingly, need to acquire new and develop their existing competences with a view to accomplishing comprehensive personal development, while employers need to review existing principles of staff training and implement new ones to meet to a vital demand of the times. 
The study made by the World Economic Forum (The Future of Jobs Report, 2018) suggests that more than half of the world's workforce will need significant re-skilling and up-skilling over the next few years. This challenge will demand a completely different approach to employee self-learning and development and, thus, a revision and update of staff training strategies.

The goal of the research is to show attitudes of employees of business organisations toward their training in terms of self-learning and competence development.

The study is based on the assumption that the lack of corporate staff's competences hinders innovation, impairs the quality of activities, while the engrained conventional approach towards staff training prevents from using workplace opportunities of self-learning and competence development.

The study identifies the following real-life problem: conventional staff training programmes, principles and methods of competence development that depend on direct and virtual learning are not always effective lately.

Research hypothesis: training and competence development teams or individuals in charge of staff training in an organisation can find the right solution to the said problem in case they make changes to employees' training strategies in regard to their learning and competence development.

Problematic questions of the research: are the acquisition of competences, trainings held, and employee self-learning considered as identical phenomena? What is the efficiency of staff training and competence development activities or the learning tools applied? What are the necessary strategic changes to staff training so as to use the opportunities for self-learning and competence development offered by a workplace? What does the application of the principles of staff training and competence development in an organisation mean in practice?

Research methods: analysis of scientific literature, online survey.

\section{Theoretical Assumptions of the Research}

According to the World Economic Forum (The Future of Jobs Report, 2018), 80 percent of business leaders believe that the activities of corporate employee training and competence development teams, workforce strategies should be more advanced and innovative, enable employees to develop analytical, critical thinking, complex problem-solving skills, emotional intelligence, creativity, etc.

Any staff training programme or self-learning, whether it is comprehensive, meaningful or not, makes no benefit for an organisation if concepts or theoretical knowledge learned are not practiced in professional activities. On the contrary, the acquisition and development of competences is 
valuable to an organisation if meets the targets of staff development (Fournier, 2004) and if employees' competences can be compared, quantified, and analysed.

The acquisition of competences does not conflict with the transmission of knowledge for developing the desired behaviour or changes in occupation (Pennaforte, 2015). An employee applies his or her knowledge to solve a specific problem through his or her competencies. Staff training in companies will always be a cornerstone of their workforce strategies. Today, however, the acquisition and development of competences, especially multimodal ones, is a more urgent and critical objective for employee development (Pellerin, 2017).

The most advanced corporate staff training teams consider independent and unplanned employee learning activities in developing the target competences as the core of their strategies (Tardif, 2013). They rely on data on employees' selflearning and self-development, are constantly on the lookout for new learning and development opportunities, and align them with corporate objectives.

Whilst most companies are taking initiatives to upgrade employee skills, employees themselves are well aware that the skills they have today will not be the same in a few years. A study by the Gartner Institute shows that only 20 percent of employees are confident of having the competences they will need in the near future (Gartner, 2018).

There must be a change in a situation of corporate staff training. Former human resource departments were not focused on advanced staff training practices, specifically, on independent or gradual learning with the use of multimedia tools, professional networks, and/or computer software. The world's most innovative staff development teams are revising workforce strategies to support self-learning initiatives.

Employee training and learning programmes make a significant portion of a training team's supply and corporate budget expenditures. A large part of employees, managers and leaders, nonetheless, do not acquire any competences during such programmes (Ručinskas, 2014). Nowadays, employees tend to study independently or together with their peers; therefore, official corporate training programmes are used much less. After all, self-learning and integration thereof in professional training save employees' time, associate learning with a specific problematic situation, and enable interaction with other, more experienced employees (Leclerc, Bourassa, \& Filteau, 2010). That's why the most advanced staff training teams focus on ensuring that people have the right resources, i.e., the right content, tools, peers, and information, rather than just the availability of training programmes. Such teams not only build a general scheme of staff training but enable employees to learn independently, too. Sometimes, employees just want to perform efficiently. The smartest staff 
training teams can spot this difference and launch the right staff training strategies.

To move forward and seize opportunities, the most innovative staff training teams seek to ensure that employee training is not just a content or their experience, but their identity, as well (Voyer, 2010). Comprehensive data on self-learning needs taking into account of when, where, how, and in what environment employees can acquire knowledge, upgrade their skills, and construct their professional identity. Since, even in a COVID-19 pandemic, competences are a critical criterion for staff development in most businesses (Le Boterf, 2020) leaders of staff training teams have the opportunity to restructure their operations. With a consumer-centred approach and the right data, with the right competence development strategy, a business and a company itself may move forward. Instead of building up a training content, innovative staff training leaders should now create conditions for self-learning, better integrate selflearning into the workflow and occupational activities. The up-skilling would become a regular practice in this case. Professional andragogues might assist or work in teams and establish consistent self-learning practices, provide better tools to support such practices (Jatkauskienè, Trakšelys, 2015). A more diverse self-learning ecosystem (a complex of appropriate tools, content, professionals, and information) makes it easier for employees to integrate learning into their daily activities and enables them to acquire the competences they need in the way that works best for them.

Assessment becomes a major factor of professionalisation and professional incentives. Staff training teams can offer assessment methods and approaches that help employees understand gaps in knowledge or skills by playing important professional roles and involving effectively in the professionalisation process (Gauthier, 2020). This allows employees to keep up with progress and to achieve their personal or corporate strategic goals, because an individual assessment procedure and comparison of competences are followed by alignment of the need for employees' competences with broader business objectives.

\section{Research Methodology}

Scope of the research. There was criterion sampling applied in the study. Questionnaires were only sent to organisations with a number of employees from 100 to 149, as they usually have staff training teams or designated employees in charge of staff training. According to Lithuanian official statistics (Official Statistics Portal, 2020), there were 495 enterprises operating in the Republic of Lithuania, with 100 to 149 employees at the beginning of 2020. The number of companies in Lithuania with this indicator is the largest one 
compared to other companies with 100 to 1000 employees. There were 400 questionnaires emailed to various companies by asking them to distribute the survey to their staff. In total, 1322 persons from 324 different companies responded to the questionnaires. There were more women $(64 \%)$ rather than men (36\%) engaged in the study. By age, 46-60 years old respondents made the smallest share (16\%), and 30-45 years old respondents - the largest share (53\%). By education, the majority of employees had higher (46\%) or vocational education (47\%), the rest (7\%) - graduated from secondary or primary schools.

The research tool (survey) was developed according to scientific publications and previous studies in the databases (EBSCO, etc.). The following keywords were used: employee development, staff training, work-based learning, competence development. The questionnaire consists of questions that are grouped into several separate blocks: 1, 2, 3, 4 (Table 1).

Table 1 Structural Blocks of Survey Questions

\begin{tabular}{|l|l|l|l|l|}
\hline $\begin{array}{c}\text { Question } \\
\text { block }\end{array}$ & $\begin{array}{c}\text { Block 1 } \\
\text { Demographics }\end{array}$ & $\begin{array}{c}\text { Block 2 } \\
\text { Acquisition of } \\
\text { competences, } \\
\text { training and } \\
\text { learning }\end{array}$ & $\begin{array}{l}\text { Elfectiveness of tools of } \\
\text { staff training, } \\
\text { competence development } \\
\text { activities, and learning }\end{array}$ & $\begin{array}{c}\text { Application of new } \\
\text { principles of } \\
\text { employee training } \\
\text { and competence } \\
\text { development }\end{array}$ \\
\hline $\begin{array}{l}\text { Content of } \\
\text { question } \\
\text { blocks }\end{array}$ & $\begin{array}{l}\text { Respondents' } \\
\text { age, gender, } \\
\text { length of } \\
\text { service in the } \\
\text { company }\end{array}$ & $\begin{array}{l}\text { Respondents' opinion } \\
\text { on the acquisition of } \\
\text { competences, the } \\
\text { importance of } \\
\text { learning and training, } \\
\text { the needs of future } \\
\text { competences }\end{array}$ & $\begin{array}{l}\text { Respondents' opinion on } \\
\text { the effectiveness of tools } \\
\text { of staff training, } \\
\text { competence development } \\
\text { activities, and learning, on } \\
\text { factors that constrain } \\
\text { training and competences, } \\
\text { etc. }\end{array}$ & $\begin{array}{l}\text { Respondents' opinion } \\
\text { on the principles of } \\
\text { employee training and } \\
\text { competence } \\
\text { development, } \\
\text { application thereof }\end{array}$ \\
\hline Questions & $1-3$ & $3-5$ & $6-12$ & $13-18$ \\
\hline
\end{tabular}

As the table demonstrates, titles of question blocks correspond to the main survey questions, and more detailed questions of each block help to delve into the main problematic questions of the research.

Data collection methods: a quantitative research strategy (anonymous questionnaire) was chosen.

Data analysis methods. SPSS (Statistical Package for Social Sciences) version 21.0 for Windows and Microsoft Excel were used for statistical data analysis. The Pearson chi-square $(\chi 2)$ criterion was used to assess the correlation between the categorical variables analysed. The Spearman's correlation coefficient of $0.2<\mathrm{r}<0.5$ weak correlation, $0.5<\mathrm{r}<0.7$ moderate, and $0.7<\mathrm{r}<1$ strong correlation was used to examine the relationship among rank data. The variance was considered statistically significant at $\mathrm{p}<0.05$. The difference in results was considered statistically significant at $\mathrm{p} \leq 0.05$. 
Research constraints. The following samples were not included in the survey: (a) companies/groups with less than 100 employees, as they usually do not have teams or individuals in charge of staff training or competence development; (b) non-full-time employees, as they may not be aware of how staff training and skills development takes place in large businesses; (c) public sector enterprises, as, for example, civil servants usually undergo training and competence development under specific and state-approved programmes; (d) providers of training services or curators thereof, as their knowledge of staff training and competence development might have some impact on results of the study.

There were ethical principles followed during the study.

\section{Research Results}

Acquisition of competences, staff training, and self-learning. To make sure that staff training strategies and investments in employee training transform into specific results, those in charge of staff training (usually, their teams) and forward-thinking people are beginning to separate staff training from the acquisition of competences.

The study raises the question whether training for employees, self-learning, and the acquisition of competences are identical phenomena.

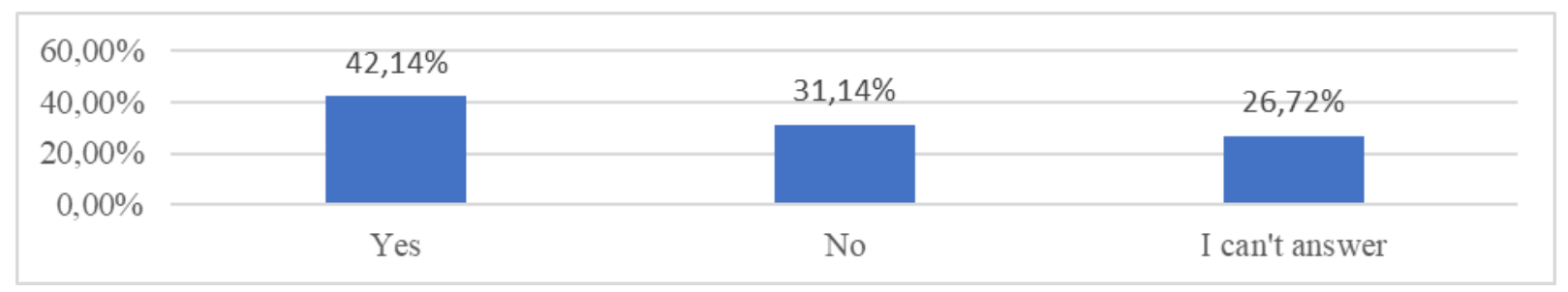

Figure 1 Equation of Competence Acquisition, Training and Self-learning Phenomena (Percentage)

As many as 42.14 percent of study participants believe that training, selflearning, and competence acquisition are identical. The acquisition of competences, training and learning are rather equated by older respondents (68.34\%) belonging to the age group of 45 to 60 than of 30 to 45 years old respondents $\left(\chi^{2}=47.71, \mathrm{df}=4, \mathrm{p}<0.001\right)$. A statistically significant difference $(\mathrm{p}=0.000<0.05)$ and a statistically significant direct, weak correlation $(\mathrm{r}=0.292$, $\mathrm{p}=0.00<0.05$ ) were found between the education background and a failure to answer the question. Based on the above, it can be stated that the higher the education, the fewer (only 9.32\%) responses 'I can't answer' are. No statistically significant differences were found when analysing the data by 
gender ( $\mathrm{p}=0.970>0.05$ ). The gap between the competences to be acquired or required for employees and the training of employees makes a certain impact. For example, some managers, which are leaders at the same time, want to achieve a measurable result in their competences through innovative staff training strategies, though in practice we can often see that many other managers still seek for training in knowledge transfer, memorisation, surveys for the evaluation of training content, and assessment of acquired knowledge. Effective staff training is argued to involve three different approaches: 1) competence development, 2) transfer of knowledge conveyed during the training to professional activities, and 3) construction and mastery of practical situations (Fournier, 2004). And then only we can talk about the enforcement of effective staff training strategies.

According to the majority of survey participants, it is possible (36.17\%) or partially possible $(45.24 \%)$ to solve any professional or personal problems through training.

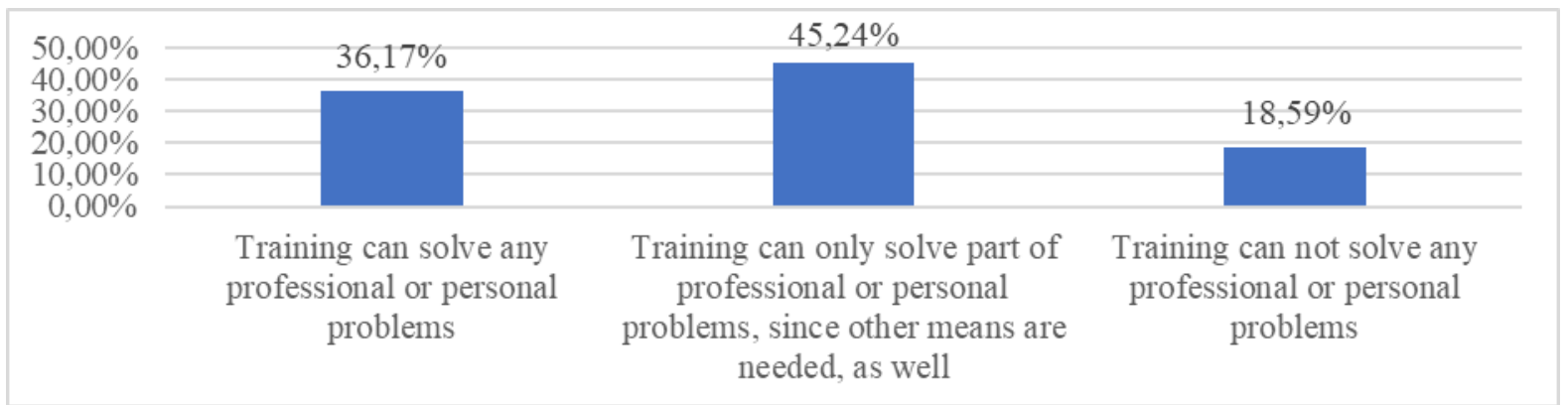

Figure 2 Training-Provided Opportunity to Solve Arising Problems (Percentage)

A statistically significant difference was found between all age groups (1$\mathrm{p}=0.002 ; 2-\mathrm{p}=0.006$; $3-\mathrm{p}=0.011 ; 4-\mathrm{p}=0.001$ ). For this reason, we assume that the increasing age of the subjects and the training-provided opportunity to solve the arising problems are related to the perception of older people that training cannot solve all the encountered problems. Yet, when comparing the available data by education, there were no significant differences $(p=0.379>0.05)$. Such an attitude can negatively affect the development of employees in acquiring and improving professional competences. The training, which is limited to the transmission of knowledge and learning activities, without putting knowledge into practice, usually fails to solve any specific professional or personal problem.

According to the study participants, future (in 5 years) professional activities and personal life will demand different competences (43.21\%). No statistically significant difference was found between women and men $(\mathrm{p}=0.574>0.05)$. 
Effectiveness of tools for staff training, competence development activities, and learning. In total, 59.54 percent of respondents stated that there was a person in the company in charge of staff training. The availability of staff training teams was, however, indicated only by 19.32 percent of study participants.

The study found that the average performance evaluation score of those in charge of staff training was only 3.06 out of 10 possible. There was a statistically significant, weak correlation $(\mathrm{r}=0.324, \mathrm{p}=0.000<0.05)$ among individuals with different education background. Based on the above, an individual's education background can be argued to influence the average evaluation score, that is, respondents with higher education rated the performance of persons in charge of staff training with a higher degree (4.2) than respondents with secondary (1.8) or vocational education (3.2).

Only one in five employees (34.4\%) approves their corporate staff training plan; almost half (48.63\%) criticise it:

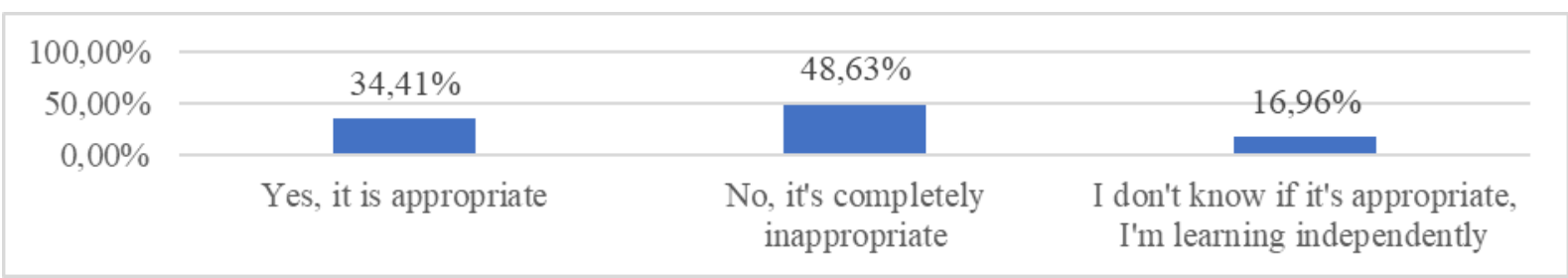

Figure 3 Respondents' Attitudes toward a Corporate Staff Training Plan (Percentage)

In this study, low estimates of a staff training plan indicate that respondents are either unaware of learning opportunities in their organisation or are simply not offered any appropriate opportunities or tools. Therefore, 16.96 percent of respondents anticipate their learning and competence development activities to fill the gaps. There were statistically significant differences among respondents with different education background $(\mathrm{p}=0.004<0.05)$, as well as statistically significant correlation, though, weak one $(\mathrm{r}=0.234$, $\mathrm{p}=0000<0.05)$. Therefore, it can be assumed that respondents with a higher degree are more in favour of their staff training plan.

The study participants indicated that, while properly performing their job duties, the following is essential for them: 
SOCIETY. INTEGRATION. EDUCATION

Proceedings of the International Scientific Conference. Volume IV, May $28^{\text {th }}-29^{\text {th }}, 2021.30-47$

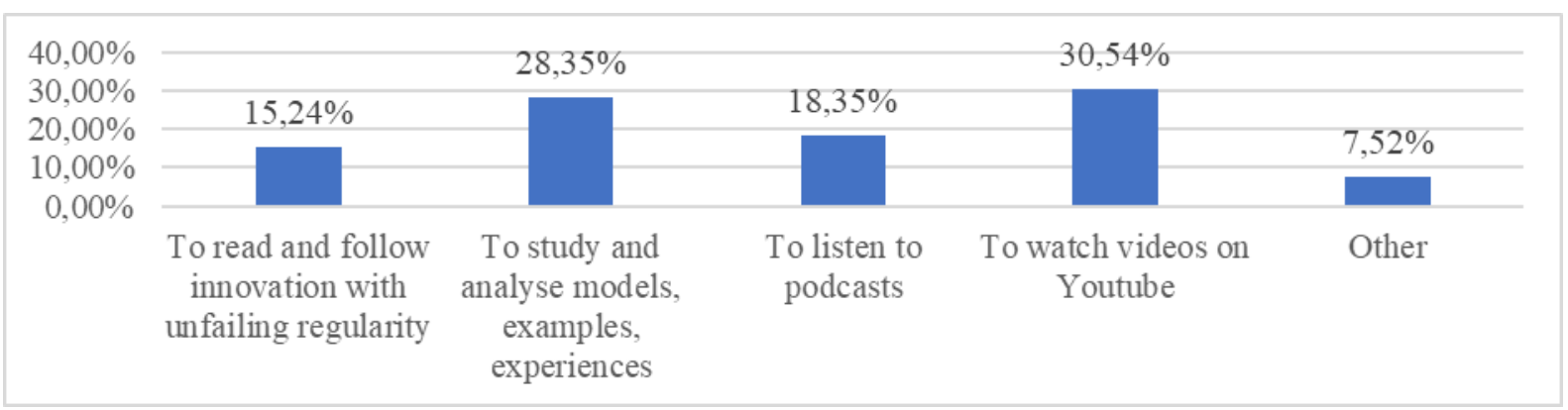

Figure 4 Forms of Self-learning From the Respondents' Point of View (Percentage)

The above data suggest that employees tend to choose different forms of self-learning. Self-learning based on digital literacy is dominating. Analysis of data among age groups shows a statistically significant difference $(\mathrm{p}=0.000$ $<0.05)$ and a statistically significant, negative, and weak correlation $(\mathrm{r}=-0.259$, $\mathrm{p}=0.000<0.05$ ). Therefore, it can be argued that the diversity of forms of independent learning decreases with age. Older respondents are less likely to choose contemporary forms of learning (podcasts, Youtube). However, $<\ldots$ combination of different forms of self-development> is particularly important for the professionalisation of employees (Roquet, 2014).

There are many ways to better respond to the needs of employees and provide everyone with the right opportunities for improvement. One of them is strategic changes to staff training. The study identified which major strategic changes to staff training should be of most concern to an organisation:

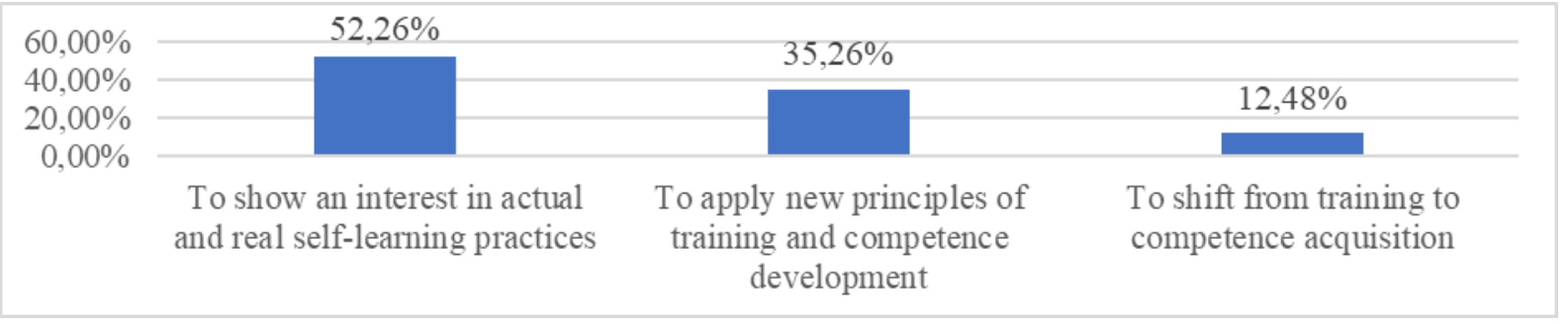

Figure 5 Percentage of Attitudes toward Major Strategic Changes to Staff Training

The majority of survey participants (52.26\%) were in favour of showing an interest in actual and real self-learning practices of employees. This means that employees want to draw attention of those responsible for staff development to what is really going on and to the fact that learning takes place independently through various forms of self-learning, and not just through involvement in training. This attitude of research participants is basically associated with another strategic change to staff training: to apply new principles of staff training and competence development, which was supported by 35.26 percent of all respondents. As just a small part of the research participants distinguished 
among self-learning, training, and competence development, it was not surprising that only $12.48 \%$ of study participants supported the strategic change in education: the shift from training to competence acquisition. Analysis of the data shows no statistically significant difference between the respondents' genders and education background $(\mathrm{Z}=-0.623, \mathrm{p}=0.533>0.05)$; the changes were evaluated similarly. However, a statistically significant difference was found by age ( $p<0.05)$, i.e., younger people were more active in supporting the shift from training to the acquisition of competences.

The study shows which self-learning tools are most often used by respondents:

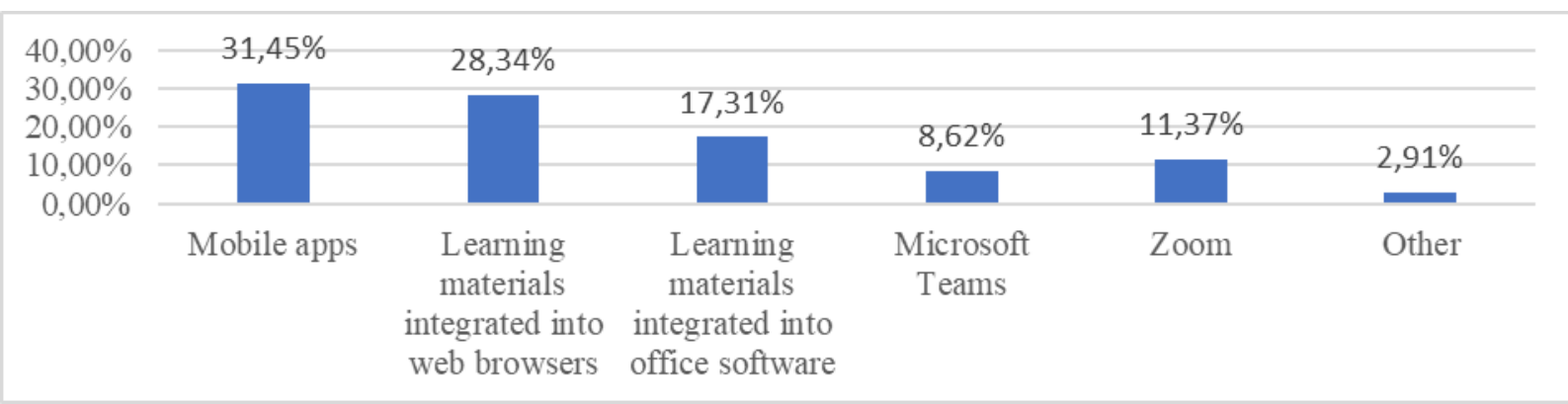

Figure 6 Percentage of Attitudes toward Self-learning Tools Used

It is very important to have and use the right tools when learning independently. Learning is possible anywhere, not only in a dedicated space. The study, however, reveals that some tools (especially, certain mobile apps) are more conducive to learning than others (31.45\%). Employees want learning materials to be integrated into web browsers (28.34 percent) or office software (17.31 percent). Collaboration tools like Microsoft Teams or Zoom web conferencing are actually less interesting for them. As for older people, there was a statistically significant in choosing mobile apps as learning tools $(p=0.000<0.05)$, with quite fewer older respondents choosing them. Therefore, the age can be assumed to determine a choice of self-learning tools.

Tools, used for employee self-learning, can be supportive, though, require free and unrestricted access to recommended learning resources in a workplace. Besides, an individual needs to know how to use software (such as Google, Word, Excel, PowerPoint, Messenger, Facebook, etc.) for work and learning. The survey found that the majority (42.44\%) of respondents had free and unrestricted access to information sources, as well as the skills of using software. But still, a sufficient number of employees (32.1\%) say they do not need any free and unrestricted access to information sources because they do not know how to use popular applications. This tendency is observed in persons of over 60 years of age and with lower education background (statistically 
significant difference $(\mathrm{p}=0.010<0.05)$ and statistically significant correlation). Therefore, without a proper analysis of the situation, it would be difficult to talk about the effectiveness of staff training, competence development activities or learning tools.

Strategic changes to the principles of staff training and competence development. Participants were asked to indicate obstacles to work-based learning. Their responses were distributed as follows:

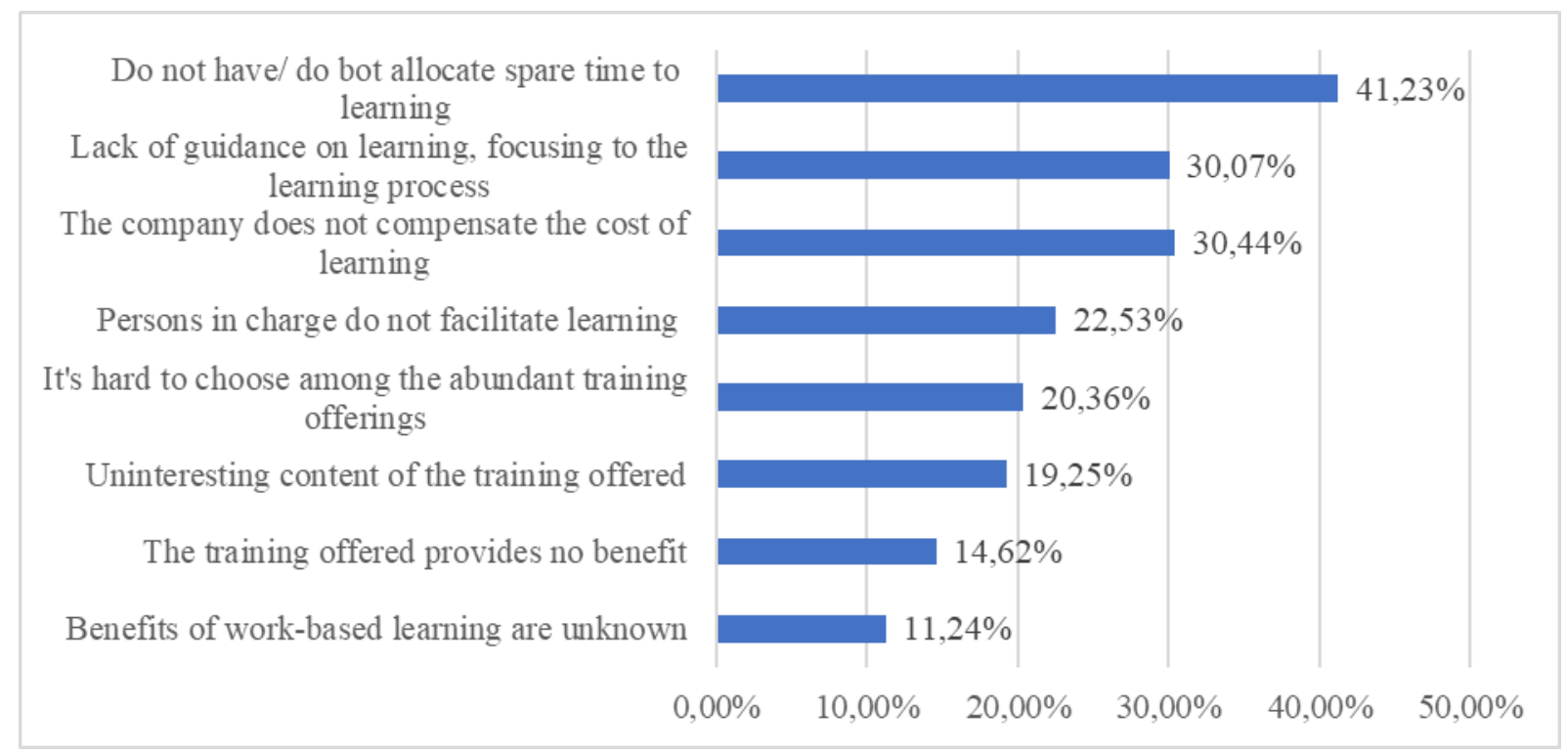

Figure 7 Percentage of Respondents' Attitudes toward the Most Common Obstacles to Work-based Learning

As the results of the study show, there are plenty of learning obstacles. The study found that the biggest obstacle to learning was lack of time $(41.23 \%)$. Analysis of demographics identifies a statistically significant correlation between younger people and the lack of time for learning in the workplace: the correlation was very weak $(\mathrm{r}=-0.180, \mathrm{p}=0.005)$. Therefore, we can assume that the high employment of younger people and the lack of professional experience may influence the evaluation of this obstacle. Most of the obstacles could be overcome if staff training teams or those in charge of the field addressed them more closely and discussed them with staff. Some need encouragement, others need advice, counselling, or guidance. So, it can be assumed that teams lack professional andragogues, as in Lithuania, persons in charge of staff training usually do not have any degree in andragogy (Jatkauskienè, 2013).

Analysis of the respondents' attitude to the application of the principle of Shifting from employee training management to competence development incentives allows observing that 27.7 percent of respondents are not satisfied with their organisation's approach to the above principle in employee training. 
They criticise the lack of clear priorities (9.25\%), low investment in staff training (10.24\%), limited and inconsistent learning opportunities (8.21\%). Nevertheless, younger and more educated advocates of the approach (66.37\%) support staff training strategies in their companies $\left(\chi^{2}=5,284 \mathrm{df}=1, \mathrm{p}=0.022\right)$. They indicate smarter planning of a staff training content $(23.43 \%)$ and more relevant and diverse learning opportunities (25.32\%). How can this difference be explained? Apparently, for those who do not support the application of the principle of staff training activities, staff training is a closed, vertically managed field, where a training content is planned and developed by persons in charge of employee training. For those who are positive about staff training, it is an open field that provides tools for progress in learning and competence development.

During the survey, it was asked whether the application of the principle of Shifting from the formation of staff training content to the creation of learning environment is observable in a company. The answers of respondents distributed as follows:

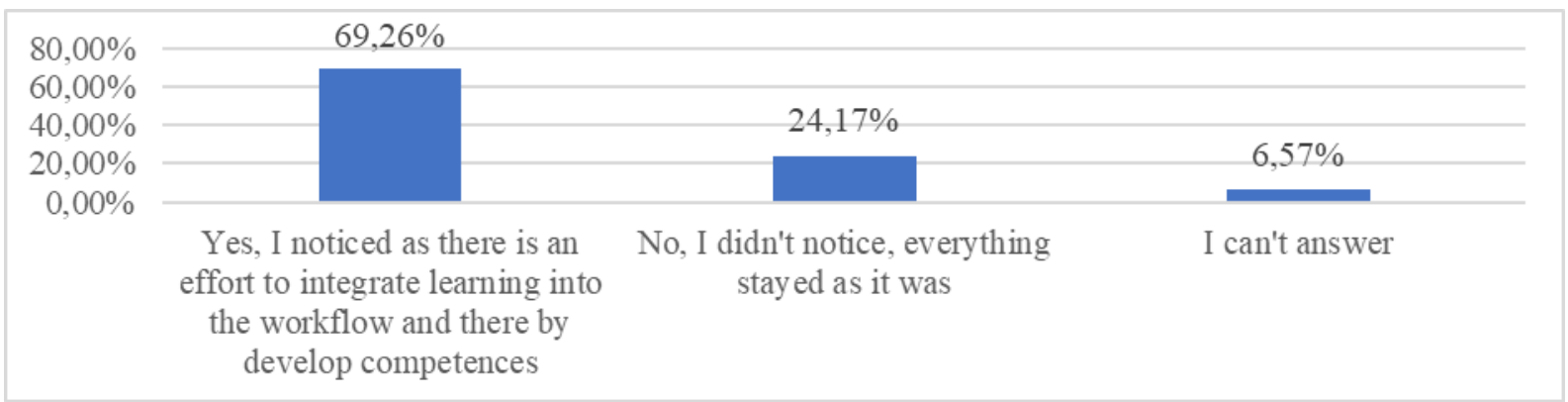

Figure 8 Percentage of Attitudes toward the Application of the Principle of "Shifting from the Formation of Staff Training Content to the Creation of Learning Environment"

Most respondents (69.26\%) observe the application of the new principle of Shifting from the formation of staff training content to the creation of learning environment in corporate staff training. The majority of those with higher education background (81.5 percent) responded to this question positively, compared to those with secondary education $(63.4 \%)\left(\chi^{2}=15.649\right.$ $\mathrm{df}=1, \mathrm{p}<0.001)$. The other part $(24.17 \%)$, which is almost identical to the respondents who spoke negatively regarding the first principle, did not observe any changes in staff training. It is worth noting that in the past, staff training teams used to develop training content for an audience. Today, however, it is not the creation or development of training content that is becoming more relevant, but rather the creation of conditions for learning in the workplace, “... the possibility to self-assess one's own learning through reliable means” (Cosnefroy, Fenouillet, \& Heutte, 2020, p. 257). 
Employees who see that their employer is investing more in their development are more satisfied with the performance of a staff training team. Therefore, respondents were asked whether the application of the principle of Shifting to an integrated learning ecosystem is perceptible in their organisation. There were $32.25 \%$ of those who noticed that employers invested more in staff training and $30.17 \%$ of those who saw the possibility to choose how and where to study without harming themselves and the company. A smaller proportion of older people (over 60 years old) were found not to feel like shifting to an integrated learning ecosystem (22.8\%) compared to younger people (30-45 years old $)(38.3 \%)\left(\chi^{2}=4.256, \mathrm{df}=1, \mathrm{p}=0.039\right)$. Such findings are associated with the transition to an integrated learning ecosystem. However, a portion $(19.28 \%$ and $14.43 \%$ ) of respondents did not observe any transition to the aforementioned learning ecosystem. One possible solution to put the principle into practice would apparently be to increase the provision of counselling and information resources (not only financial) to employees and “...tolerance of certain errors in their activities” (Lauzier, \& Mercier, 2018, p. 59).

Businesses have procedures in place to assess employee performance and competences. The study was aimed to find out whether those responsible for staff training in an organisation provided the necessary support/assistance in the following assessment situations:

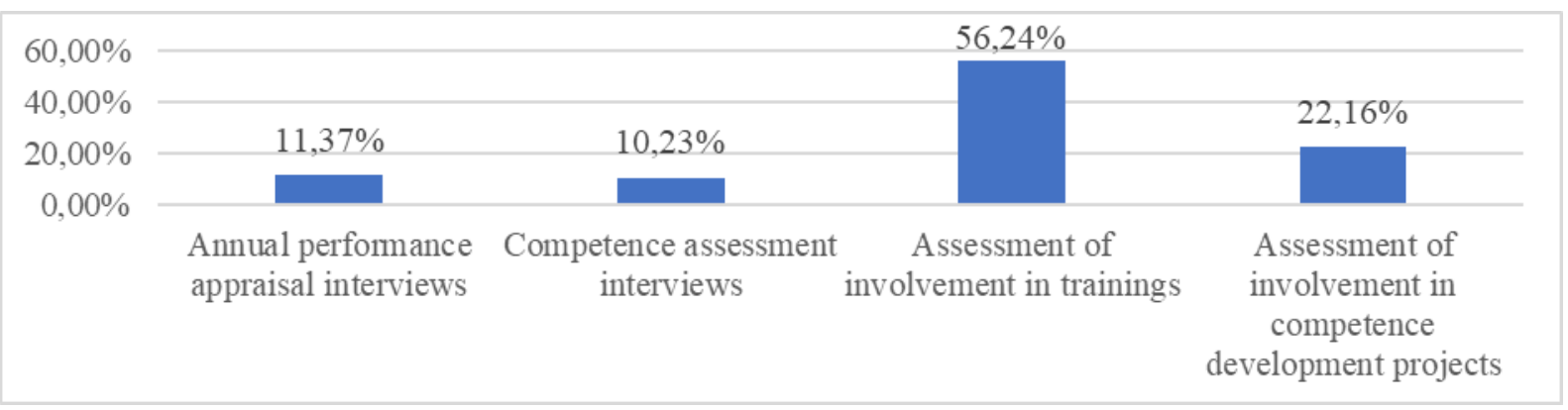

Figure 9 Percentage of Attitudes toward the Assessment of Employees' Performance, Competences, and the Support/Assistance Received During It

As the above survey data show, companies are running various assessment procedures. However, from the respondents' point of view, assistance from those in charge of staff training in annual performance appraisal interviews (11.37\%) or competence and knowledge assessment interviews (10.32\%) is provided at a minimum. More assistance is provided in assessing employee participation in training programmes (56.24\%) and competence development projects (22.16\%). There was no statistically significant difference between the study data by age groups and education $(\mathrm{p}=0.826>0.05)$. Therefore, we can assume that the attitude toward the assessment procedures and the support/ assistance received 
does not depend on age or education. Assistance is received rather in simpler issues, where it is easy to see the level of knowledge or intensity of involvement of an employee. Meanwhile, the level of competences and assessment thereof is subject to the assessors' attitude, the methodology chosen, and the consensus on the object to be assessed (Le Boterf, 2018).

During the study, it was asked which of the available proposals for the development of competences would best meet objectives of employees' selflearning and career aspirations. Answers of the respondents were distributed as follows:

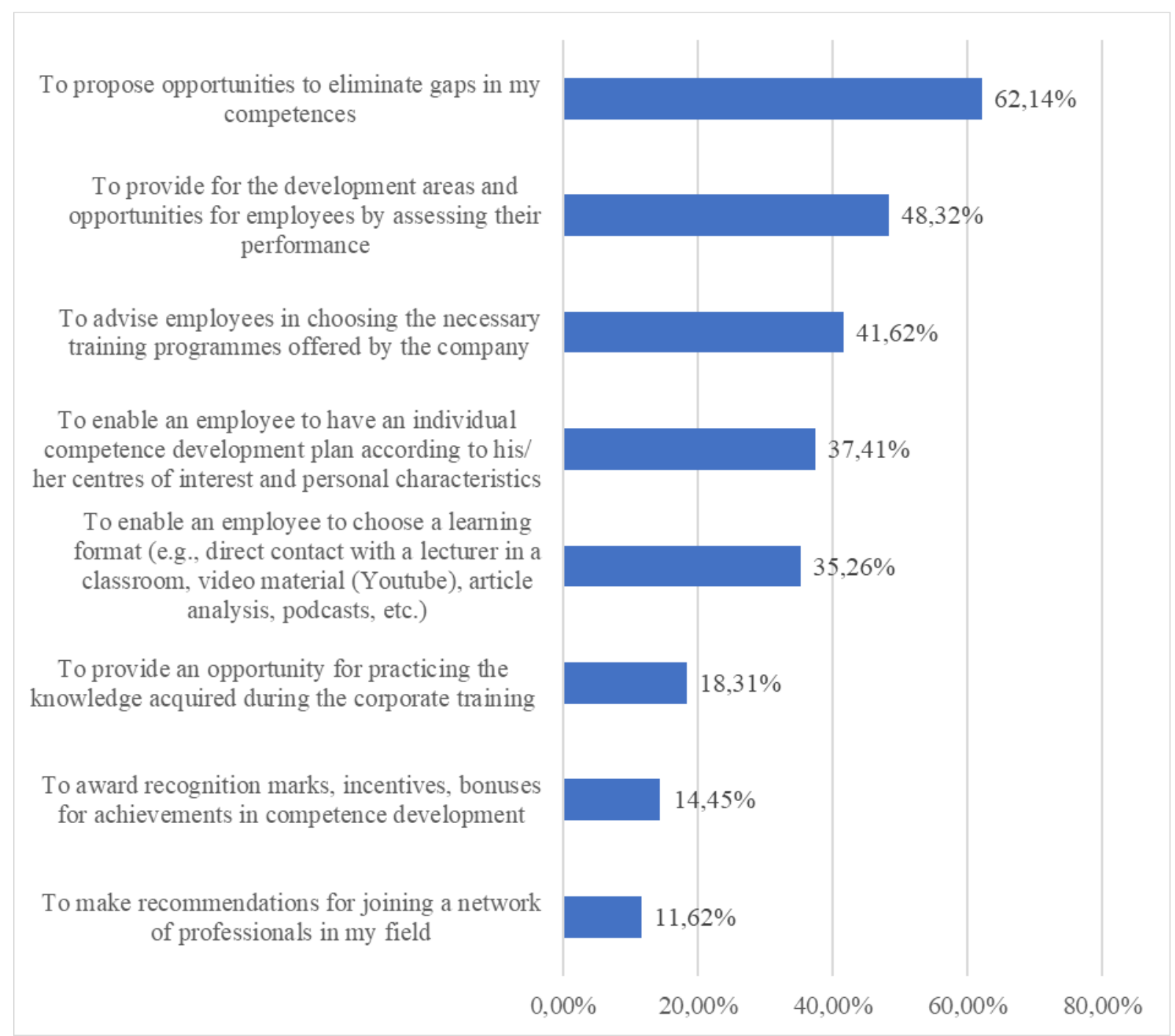

Figure 10 Percentage of Attitudes toward Competence Development Opportunities

The research data demonstrate that the statement "To propose opportunities for eliminating gaps in my competences" is dominating, i.e., 62.14 percent. There is a statistically significant difference $(\mathrm{p}=0.001<0.05)$ in the age group 
(45-60 years of age). So, it can be argued that fewer older people support the above statement (43.25\%) because they have more experience and, possibly, see no competence gaps. In this case, we need to be especially clear: what motivates employees to learn is the benefit they get from learning. This motivation is one of the most powerful factors in employee involvement in learning activities and competence development (Tremblay, Chênevert, \& Hébert, 2012). The proposal "To provide for the development areas and opportunities for employees by assessing their performance" received a little less support (48.32 percent), since only this assessment allows a learner to surpass himself or herself (Laveault, 2019). Respondents were quite active in supporting the proposal "To advise employees in choosing the necessary training programmes offered by the company" (41.62 percent). Even the most self-sufficient employees need support and advice (Pennaforte, 2015). Our research shows a lack of encouragement, recognition, and advice. Improvement of management practices is a great opportunity for staff training teams or those in charge thereof to pursue more effective performance. An annual performance review is not enough. Employees are happy when their supervisor recommends training programmes, offers opportunities for improvement, and approves the right competence acquisition goals.

\section{Conclusions}

The empirical study suggests that its hypothesis is validated. The study has found that although the acquisition of competences, trainings held, and employees' self-learning are not identical phenomena, almost half of the study participants do not distinguish among them. Accordingly, the abovementioned part of respondents is not aware that training covers the transmission of information and knowledge, while learning - perception and memorisation thereof, and that this does not necessarily mean putting knowledge into practice, competence development, or a positive effect on professional activities.

Most of the research participants believe that training makes it possible or partially possible to solve any problems of a professional or personal nature. This attitude should be treated as a negative factor in staff training strategies in the acquisition and development of professional competences.

The research participants believe that they will need different competences in the future, therefore, the revision and upgrading of staff training strategies is the matter of topical interest.

According to more than half of the survey participants, their organisations have persons in charge of staff training, however, their staff training and competence development activities, as well as the effectiveness of the measures taken were rated as low on average. So, only one in five respondents approves 
their organisation's staff training plan, which can be attributed to the ineffectiveness of existing employee training measures.

The study has revealed that employees learn independently through a variety of channels and formats. The practice of those responsible for employee training would receive greater recognition if they integrated various learning opportunities, such as analysis of experiences, examples, videos, podcasts, etc. into the professional activities of employees. Just as well the respondents consider self-learning to be dominated by multimedia tools, smartphones, tablets, software applications, professional networks, and so no. Such selflearning activities might be attributed to a company's efforts to train its employees. However, there is a lack of insight into the competences acquired by employees through self-learning. With incomplete data on employee selflearning and learning objectives, those in charge of staff training are only able to provide standardised and fundamentally ineffective staff training strategies. Therefore, the employee self-learning datasets, currently used by many innovative companies, should be enlarged.

The study highlights the main preferred strategic changes to staff training so as to use the opportunities for self-learning and competence development offered by a workplace. More than half of the survey participants are in favour of showing more interest in actual and real self-learning practice of employees. More than a third of all respondents support new principles for employee training and competence development, which enable the integration of selflearning into professional activities as a place for self-improvement and competence development. More than half of the survey participants are in favour of shifting from training to the acquisition of competences, by adapting the competence assessment to the elimination of the identified gaps.

More than half of the survey participants observe the application of new, strategically important principles of staff training in a company. The rest of respondents, however, are sceptical and do not see any change. For those who speak positively about the application of the strategic principles for staff training in a company, training means an open area that provides greater opportunities for progress in independent learning and competence development. On the contrary, for those who are against staff training - it is a closed, vertically managed field, where a content, tools, and resources are planned and developed by persons in charge of employee training, thus, constraining human curiosity, creativity, free choice, and initiative.

It is suggested for corporations: to be open to employees' wills and seek to implement strategic changes to employee development by integrating selflearning into daily independent activities; to show interest in actual and real selflearning practice of employees; to apply new principles of staff training, by shifting from employee training management to competence development 
SOCIETY. INTEGRATION. EDUCATION

Proceedings of the International Scientific Conference. Volume IV, May $28^{\text {th }}-29^{\text {th }}, 2021.30-47$

incentives, from the formation of staff training content to the creation of learning environment and an integrated learning ecosystem; to move from training to the acquisition of competences, by adapting competence assessment to the elimination of identified gaps.

\section{References}

Cosnefroy, L., Fenouillet, F., \& Heutte, J. (2020). Construction et validation de l'Échelle d'autorégulation des apprentissages en ligne (EAREL). Canadian Journal of Behavioural Science, 52(3), 255-260. Retrieved from https://ezproxy.biblioteka.ku.lt: $4400 / 10.1037 /$ cbs0000147

Fournier, P. S. (2004). Soutenir le développement de compétences par la conception d'aides à l'apprentissage sur le cours de vie professionnelle. Relations Industrielles/Industrial Relations, 59(4), 744-768. Retrieved from https://ezproxy.biblioteka.ku.lt:4400/10.7202 /011337ar

Gartner, M.B. (2018). Shifting Skills Survey. Retrieved from https://www.gartner. com/en/newsroom/press-releases/2018-09-06-gartner-says-only-20-percent-ofemployees-have-the-skills-needed-for-both-their-current-role-and-their-future-career

Gauthier, B. (2020). Une analyse engagée de la professionnalisation des pratiques d'évaluation. (French). Canadian Journal of Program Evaluation, 35(1), 127-137. Retrieved from https://ezproxy.biblioteka.ku.lt:4400/10.3138/cjpe.69364

Jatkauskienė, B. (2013). Andragogu profesionalizacijos sistemos procesionali raiška (Monografija). Klaipėda: KU leidykla.

Jatkauskienė, B., Trakšelys, K. (2015). Andragogy: Adult Educational Contexts. Monografija. Scholar's Press: Saarbrücken. ISBN: 978-3-639-76708-7.

Lauzier, M. \& Mercier, G. (2018). Effets des conceptions de l'erreur, de la motivation à apprendre et du soutien social sur l'intention de transférer les nouveaux apprentissages: un modèle de médiation modérée. Canadian Journal of Administrative Sciences (John Wiley \& Sons, Inc.), 35(3), 57-67. Retrieved from https://ezproxy.biblioteka.ku.lt:4400 $/ 10.1002 /$ cjas. 1430

Laveault, D. (2019). Évaluation des apprentissages: pour être à la hauteur et se dépasser. Education Canada, 59(1), 26-28.

Le Boterf, G. (2018). Construire le compétences collectives. Coopérer efficacement dans les entreprises, les organisations et les réseaux de professionnels. Paris : Eyrolles.

Le Boterf, G. (2020). La prise en charge des covid-19: quelle situation professionnelle, quelle réponse de professionnalisme ? Gestions hospitalières, $n^{\circ}$ 597, p. 35-41. Retrieved from http://gestions-hospitalieres.fr/la-prise-en-charge-des-covid-19/

Leclerc, C., Bourassa, B., \& Filteau, O. (2010). Utilisation de la méthode des incidents critiques dans une perspective d'explicitation, d'analyse critique et de transformation des pratiques professionnelles. (French). Education et Francophonie, 38(1), 11-32. Retrieved from https://ezproxy.biblioteka.ku.lt:4400/10.7202/039977ar

Oficialios statistikos portalas. (2020). Retrieved from https://osp.stat.gov.lt/statistiniurodikliu-analize?hash=8259ee63-57f4-4c71-9dfd-4a8005126c56\#/

Pellerin, M. (2017). L’usage des technologies numériques pour le développement de compétences multimodales en littératie au 21e siècle. (French). Education et Francophonie, 45(2), 85-106. Retrieved from https:/ezproxy.biblioteka.ku.lt: 4400/10.7202/1043530ar 
Pennaforte, A. (2015). Le développement de liens d'implication multi-cibles en formationemploi: le rôle des soutiens organisationnels, du supérieur, et des collègues de travail. Gestion 2015, 32(4), 15-35. Retrieved from https:/ezproxy.biblioteka.ku.lt: 4400/10.3917/ g2000.324.0015

Roquet, P. (2014). Rhythmes dans les activités formatives et professionnelles: une compréhension des temporalités dans la construction des processus de professionnalisation. Revue Phronesis, 3(4), 56-61. Retrieved from https://ezproxy.biblioteka.ku.lt:4400/10.7202 /1028786ar

Ručinskas, A. (2014). Kompetencijų modelį taiko jau 12 metų. Valstybès kontrolès patirtis. Valstybès tarnybos aktualijos. Retrieved from http://www.vlkk.lt/media/public/file /Naujienos/VTA_rudeninis\%20(1).pdf

Tardif, J. (2013). Définir rigoureusement des trajectoires de développement pour chacune des compétences à la base de la formation. Pédagogie Médicale, 14(1, Supp), 35-36. Retrieved from https://ezproxy.biblioteka.ku.lt:4400/10.1051/pmed/2013039

Tremblay, M., Chênevert, D., \& Hébert, A. (2012). Le rôle des conditions de travail dans la satisfaction et la loyauté des infirmières d'agence au Québec. Relations Industrielles/Industrial Relations, 67(3), 477-504. Retrieved from https://ezproxy.biblioteka.ku.lt:4400 /10.7202/1012540ar

Voyer, B. (2010). L'intermittence en emploi peut-elle être une expérience formatrice? (French). Education et Francophonie, 38(1), 51-71. Retrieved from https://ezproxy.biblioteka.ku.lt:4400 /10.7202/039979ar

World Economic Forum. (2018). The Future of Jobs Report. Centre for the New Economy and Society. Geneva. Retrieved from http://www3.weforum.org/docs/ WEF_Future_of_Jobs_2018.pdf 